\title{
ANALYSIS OF CHEMICAL COMPOUNDS OF AGARWOOD OIL FROM DIFFERENT SPECIES BY GAS CHROMATOGRAPHY MASS SPECTROMETRY (GCMS)
}

\author{
YUMI Z.H-Y. HASHIM AND N.I. ISMAIL AND P. ABBAS \\ Department of Biotechnology Engineering, Faculty of Engineering, \\ International Islamic University Malaysia, \\ PO Box 10, 50728, Kuala Lumpur, Malaysia.
}

yumi@iium.edu.my

\begin{abstract}
Agarwood oil is a highly prized type of oil due to its unique aroma. The oil is extracted from the fragrant resin found in the agarwood tree (trunk). The unique aroma and quality of agarwood resin and oil are contributed by the presence of certain chemical compounds. In this work, analysis and comparison of the chemical compounds of agarwood oil from A. malaccensis, A. sub-integra and a mixture of both were conducted. The essential oils were diluted in hexane $(5 \%)$ prior to gas chromatography mass spectrometry (GCMS) analysis performed using Agilent GCMS 7890A coupled with MSD quadrupole detector 5975 C. Separation of analytes by gas chromatography was carried out using a Hewlett Packard HP-5MS silica capillary column (30 m X 0.25 $\mathrm{mm}$ X $0.25 \mathrm{~mm}$ ). A total of 107 compounds were identified from the three samples of agarwood oils. Fifty-five (55) components were identified in A. malaccensis sample which contributes to the largest portion of the total compounds. About $20 \%$ of the compounds identified were aromatic and sesquiterpenes, which have been revealed to be the main active compounds of agarwood oils which also give the aroma and pleasant odour of agarwood. Different compositions or profile of chemical components were found in agarwood oils from the two different species. Two compounds were commonly identified in all three samples, namely 3-phenyl-2-butanone and alpha-cubebene. Further studies are needed to refine the results which later can be used to assist detection and authentication of agarwood as well as its scientific-based grading.
\end{abstract}

ABSTRAK: Minyak gaharu merupakan sejenis minyak beraroma unik yang mendapat permintaan tinggi dan mahal. Minyak ini diekstrak daripada resin beraroma yang terbentuk di dalam batang pokok gaharu. Keunikan aroma dan kualiti resin dan minyak gaharu ini bergantung kepada kehadiran bahan kimia tertentu. Penyelidikan ini menjurus kepada analisis dan perbandingan bahan-bahan kimia yang terdapat dalam minyak gaharu daripada spesis A. malaccensis, A. subintegra dan campuran kedua-duanya. Minyak gaharu dilarutkan di dalam 5\% heksana sebelum dianalisis menggunakan kromatografi gas Agilent GCMS 7890A berserta spektormetri jisim (MSD quadrupole detector 5975 C). Kolum kapilari silika Hewlet Packard HP-5MS (30 m X $0.25 \mathrm{~mm}$ X $0.25 \mathrm{~mm}$ ) digunakan untuk pemisahan bahan-bahan kimia tersebut. Sejumlah 107 kompaun dikenalpasti dalam ketiga-tiga sampel minyak gaharu tersebut dengan 55 kompaun didapati di dalam sample $A$. malaccensis. Ini merupakan bahagian terbesar daripada keseluruhan kompaun. Sebanyak $20 \%$ daripada keseluruhan kompaun yang dikenalpasti adalah daripada kumpulan seskuiterpena dan bersifat aromatik, juga merupakan kumpulan yang bertanggungjawab memberi aroma yang unik kepada minyak gaharu. Setiap spesis didapati mempunyai komposisi atau profil bahan kimia yang tersendiri. Dua kompaun iaitu 3-phenyl-2butanone dan alpha-cubebene ditemui dalam ketiga-tiga sample yang dianalisis. Kajian lanjut adalah perlu untuk memurnikan dapatan hasil penyelidikan yang berpotensi bagi membantu pengenalpastian gaharu berserta pembangunan penggredan gaharu yang lebih saintifik. 
KEYWORDS: agarwood oil; A. Malaccensis; A. sub-integra; chemical compounds, GCMS

\section{INTRODUCTION}

Agarwood oil is a highly prized type of oil due to its unique aroma. The oil is extracted from the fragrant resin found in the agarwood tree trunk. The formation of resin can be stimulated through natural infection of a consortium of microorganisms, chemical induction and or artificial wounding. Since the formation of resin through natural infection is a long process with very low yield, this lends to its high price.

The unique aroma and quality of the agarwood resin and oil are contributed by the presence of certain chemical compounds. Sesquiterpenes have been reported to be the main active components that play important roles in giving the aroma and pleasant odor of agarwood [1, 2]. However, there are many other chemical compounds in the agarwood resin and oil; some of which have medicinal values. Earlier studies have focused on identification of the chemical compounds found in specific species of agarwood. For instance, sesquiterpenes were reported to be found in A. agallocha [3, 4]. There are fifteen species in the Aquilaria genus and eight are known to produce agarwood [5]. In theory, all members in Aquilaria genus can produce agarwood; however, until recently it was primarily produced from Aquilaria malaccensis. Other members of the genus that are usually harvested are A. crassna, A. sub-integra, A. agallocha and A. sinensis [6, 7].

In this work, analysis and comparison the chemical compounds of agarwood oil from A. malaccensis and A. sub-integra were conducted. The former is a local species found in Malaysia; which has connotation with superior quality of resin and oil [6]. Meanwhile, the latter, with characteristic of faster growth, is more common in Thailand and Cambodia where the species have been commercially cultivated in plantations. The characteristics of aroma between species may help in identification and authentication of agarwood as well as determination of its quality.

\section{MATERIALS AND METHODS}

\subsection{Sample Preparation}

Three types of agarwood oils produced using hydrodistillation technique were obtained from different sources. The samples were labeled sample A (A. malaccensis from Malaysia), sample B (A. sub-integra from Thailand) and sample C (mixture of $A$. malaccensis and A. sub-integra from Malaysia, Grade C) respectively. The essential oils were diluted in hexane (5\%) prior to GCMS analysis.

\subsection{Gas Chromatography Mass Spectrometry (GCMS) Analysis}

GCMS analysis was performed with a gas chromatography system; Agilent 7890A (Agilent Technologies) coupled with MSD quadrupole detector 5975 C. Separation of analytes by gas chromatography was carried out using a Hewlett Packard HP-5MS silica capillary column (30 m X $0.25 \mathrm{~mm} \times 0.25 \mathrm{~mm})$. The analytical conditions for GCMS are listed in Table 1.

The peaks from GCMS were detected based on the total ion chromatography (TIC) and mass chromatograms; and further identified using National Institute of Standards and Technology (NIST) 2008 mass spectral library. 
Table 1: Analytical conditions for GCMS analysis (based on [6]).

\begin{tabular}{ll}
\hline Program & Conditions \\
\hline Oven Program & $80{ }^{\circ} \mathrm{C}$ for $2 \mathrm{~min}$, then $10{ }^{\circ} \mathrm{C} / \mathrm{min}$ to \\
& $250^{\circ} \mathrm{C}$ for $10 \mathrm{~min}$ \\
Carrier gas & Helium \\
Gas flow & $2 \mathrm{ml} / \mathrm{min}$ \\
Split Ratio & $1: 50$ \\
Injection Volume & $1 \mu 1$ \\
Mode & $\mathrm{Splitless}$ \\
Interface temperature & $250{ }^{\circ} \mathrm{C}$ \\
Electron impact (emission & $70 \mathrm{eV}$ \\
current) & 32 to $500 \mathrm{amu}$ \\
Scan range &
\end{tabular}

\section{RESULTS AND DISCUSSION}

Examination of three samples of agarwood oils from different sources showed some variations in $\mathrm{GC}$ profile and chemical components. The variations of GC profiles are shown in Fig. 1 (A-C).

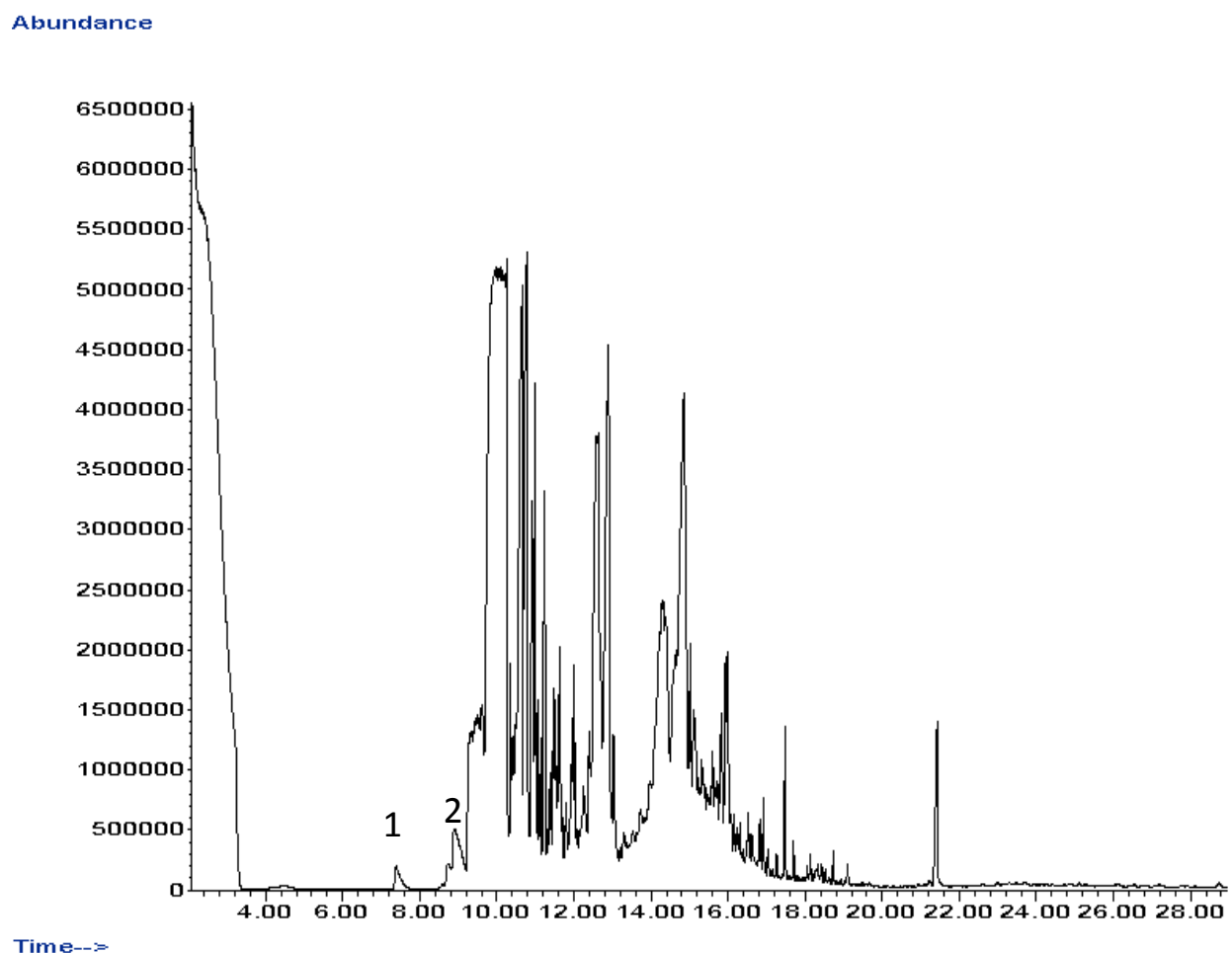

(a) 


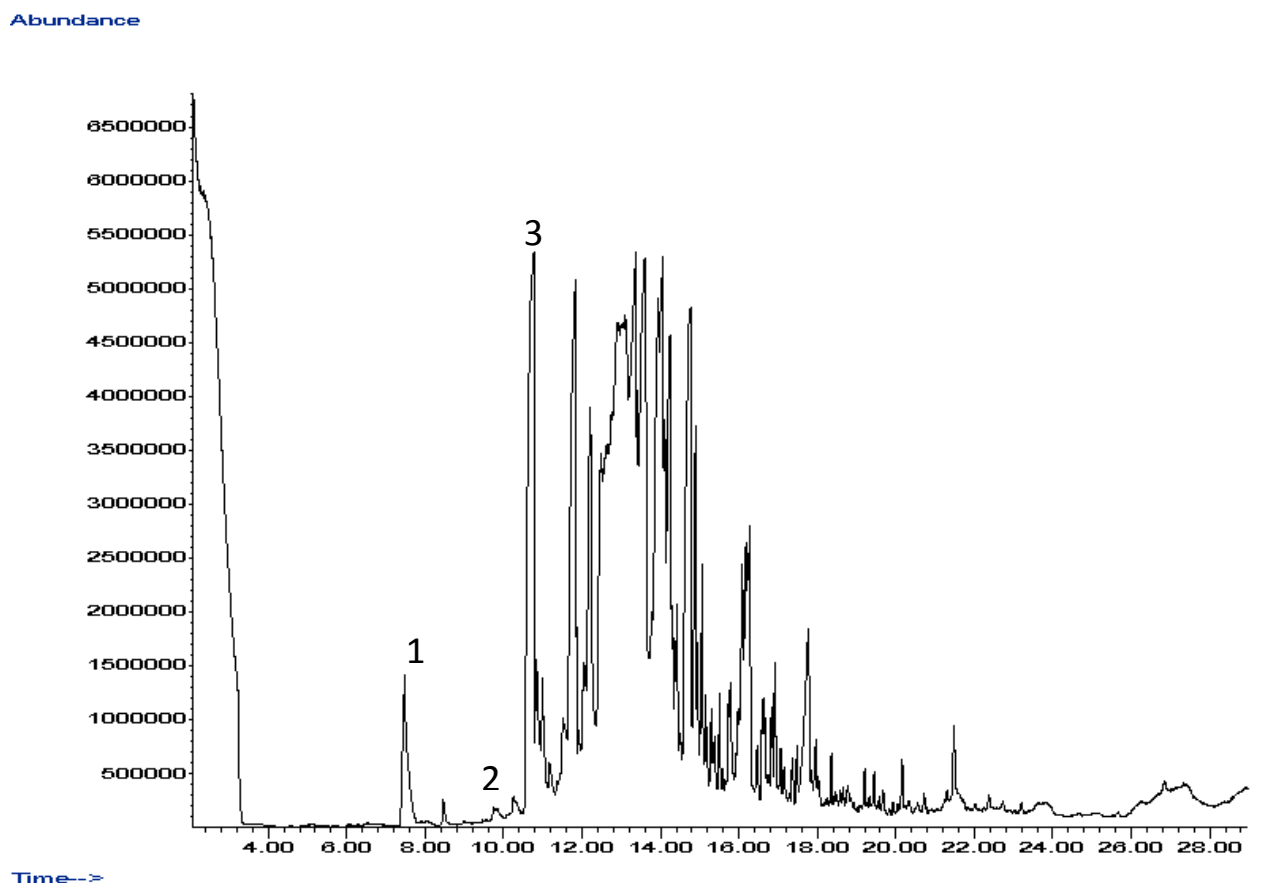

(b)

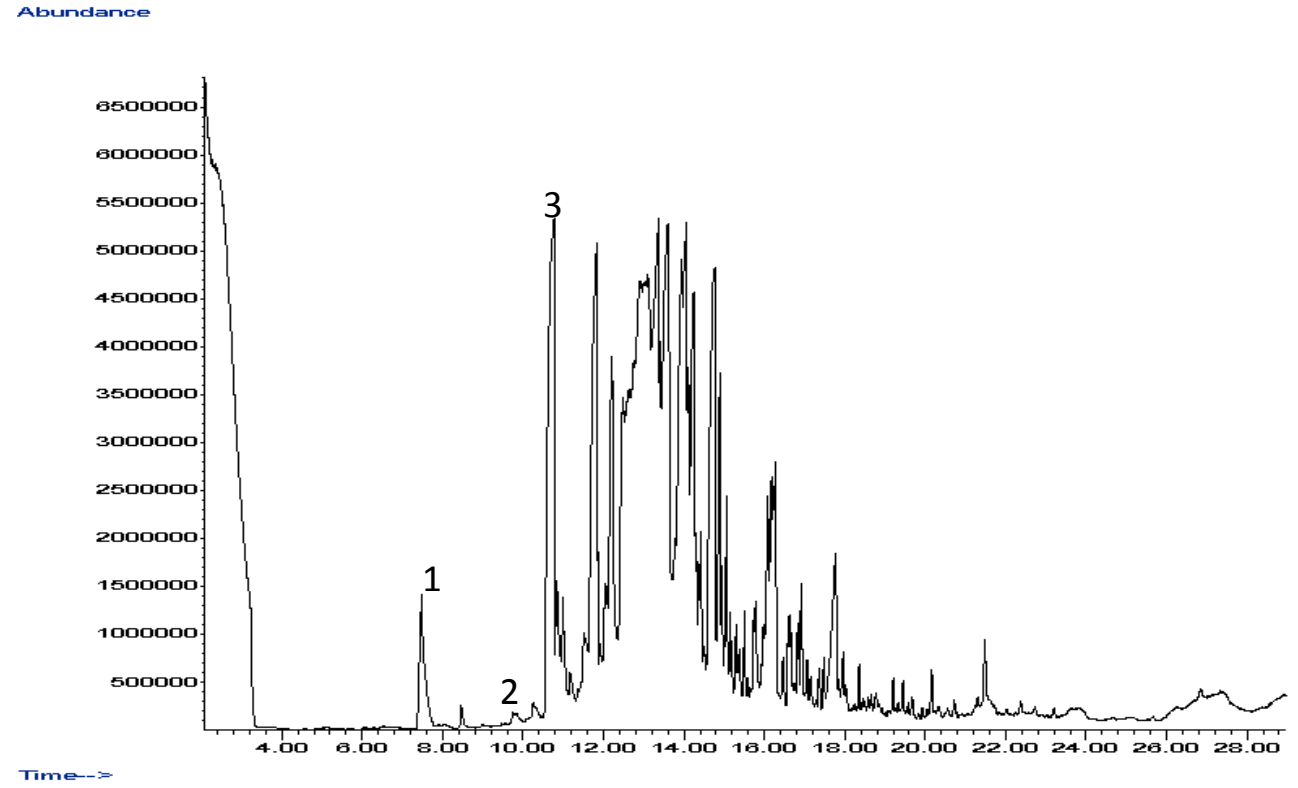

(c)

Fig. 1: Total ion chromatogram (TIC) for agarwood oil from different species. (A) Sample A (A. malaccensis from Malaysia), (B) Sample B (A. sub-integra from Thailand) and (C) Sample C (mixture for A. malaccensis and A. sub-integra from Malaysia, Grade C). Labeled peaks are 3-phenyl-2-butanone (1), alpha-cubebene (2), and globulol (3). 
A total of 107 compounds were identified from the three samples of agarwood oils. Fifty five components were identified in sample A which contributes to the largest portion of the total compounds. In sample B and sample C, there were 35 and 37 compounds identified respectively. About $20 \%$ of the compounds identified were aromatic and sesquiterpenes which have been revealed to be the main active compounds of agarwood oils. These main active components play important roles in giving the aroma and pleasant odor of agarwood [1,2].

Two compounds were commonly identified in all three samples which are 3-phenyl2-butanone and alpha-cubebene, a waxy herbal odor type with medium odor strength. Common occurrence of 3-phenyl-2-butanone, was observed in all agarwood oil ( $A$. malaccensis) obtained from different sources in Peninsular Malaysia [8]. In an earlier study, benzylacetone was also found to be major compounds found in A. malaccensis [9].

Similar compound named 1,1,4,7-Tetramethyldecahydro-1H-cyclopropa[e]azulen-4ol (also known as globulol) was identified to be present in sample B and sample C. There were 11 similar compounds identified from sample A and sample C but not sample B. Most of these compounds were sesquiterpenes such as alpha-caryophyllene (alphahumulene), alpha-calacorene. To this end, this suggests that the compounds could be potential characteristic compounds of each agarwood species. Nevertheless, further studies are needed to refine and validate these early findings.

There are several factors that may result in different chemical compositions of agarwood essential oil which include (a) species/origin of the agarwood tree, (b) methods of stimulation of agarwood resin, and (c) extraction method of agarwood oil. Our results showed that different species have different composition of chemical compounds. In another study, several sesquiterpenes were found in five different types of Chinese eaglewood essential oil [10].

The quality of agarwood oil is also affected by the stimulation method to produce the resin. Resin production can be stimulated either through natural infection, chemical induction or artificial screw techniques which wounded the trunk (nail inserting, holing and trunk breaking). Several studies have been done to compare the quality of the mantreated and wild agarwood. Chen et al. [1] investigated the chemical compositions of agarwood oil originating from resin stimulated by chemical methods. Meanwhile, Bhuiyan et al. [11] examined the difference in composition of oil obtained from naturally infected tree and artificially inoculated eaglewood (A. agallocha Robx.) by GCMS. The composition of inoculum, natural variant and specific host-pathogen relationship also play great role in inducing the resin production in agarwood [11] which relates to the quality and differential composition of chemical compounds in its resin and oil.

Further, extraction method of agarwood oil also influences the quality and chemical composition of the oil. Various techniques have been used for agarwood oil extraction: water distillation (hydrodistillation), steam distillation, solvent extraction and supercritical fluid extraction [12]. Each technique has its own advantages and disadvantages. In a study done by Pornpunyapat et al. [13], extraction of agarwood oil was performed by hydrodistillation at different temperature: $80^{\circ} \mathrm{C}, 100^{\circ} \mathrm{C}$ and $120^{\circ} \mathrm{C}$. In their findings, hydrodistillation of essential oil at high temperature $\left(120^{\circ} \mathrm{C}\right)$ gave the maximum oil yield and have better physical properties and attributes. Meanwhile, there was significant difference in the quantity of each composition and types of major components of agarwood oil extracted using supercritical fluid extraction as compared to distillation method [2]. 


\section{CONCLUSION}

In conclusion, using GCMS, we have identified different compositions of chemical components in agarwood oils from different species namely A. malaccensis and A. subintegra with two compounds commonly identified in all three samples which are 3phenyl-2-butanone and alpha-cubebene. Further studies are needed to refine the results which later can be used to assist detection and authentication of agarwood as well as its scientific-based grading.

\section{ACKNOWLEDGEMENT}

This research was jointly funded by IIUM Special Grant and Kayu Gaharu (M) Sdn. Bhd. We would like to thank everyone who contributed to this research.

\section{REFERENCES}

[1] Chen, H., Yang, Y., Xue, J., Wei, J., Zhang, Z., Chen, H. "Comparison of compositions and antimicrobial activities of essential oils from chemically stimulated agarwood, wild agarwood and healthy Aquilaria sinensis (Lour.) gilg trees." Molecules 16.6 (2011): 488496.

[2] Wetwiyaklung, P., Thavanapong, N., Charoenteeraboon, J. "Chemical constituents and antimicrobial activity of essential oil and extracts of heartwood of Aquilaria crassna obtained from water distillation and supercritical fluid carbon dioxide extraction." Silpakorn U Science \& Tech Journal, 3.1(2009):25-33.

[3] Ishihara, M., Tsuneya, T., Uneyama, K. Guaiane sesquiterpenes from agarwood. Phytochemistry, 30.10(1991):3343-347.

[4] Nakanishi, T., Yamagata, E., Yoneda, K., Nagashima, T., Kawasaki, I., Yoshida, T., Mori, H., Miura, I. Three fragrant sesquiterpenes of agarwood. Phytochemistry, 23.9(1984):206667.

[5] Eurlings, M.C.M., Gravendeel, B. TrnL-trnF sequence data imply paraphyly of Aquilaria and Gyrinops (Thymelaeaceae) and provide new perspectives for agarwood identification. Pl. Syst. Evol., 254(2005):1-12.

[6] Ng, L.T., Chang, Y.S., Azizol, A.K. A review on agar (gaharu) producing Aquilaria species. J. Trop. Forest Products, 2.2(1997):272-85.

[7] Burkill, I.H. A dictionary of the economic products of the Malay Peninsula. Ministry of Agriculture, Kuala Lumpur. 1(1966):198-206.

[8] Nor Azah MA., Chang, YS., Mailina J., Abu Said A., Abd Majid J., Saidatul Husni S., Nor Hasnida H., Nik Yasmin YComparison of chemical profile of selected gaharu oils from Peninsular Malaysia. The Malaysian Journal of Analytical Sciences. 12.2(2008):338-40.

[9] Yaacob, K.B., Joulain, D. Volatile constituents from infected wood of Aquilaria malaccensis Benth. Sains Malaysiana, 29(2000):197-200.

[10] Mei, Wen-Li., Zeng, Yan-Bo., Wu, J., Cui, Hai-Bin., Dai, Hao-Fu. Chemical composition and anti-MRSA activity of the essential oil from Chinese eaglewood. Journal of Chinese Pharmaceutical Sciences, 17(2008):225-29.

[11] Bhuiyan, M.N.I., Begum, J., Bhuiyan, M.N.H. Analysis of essential oil of eaglewood tree (Aquilaria agallocha Roxb.) by gas chromatography mass spectrometry. Bangladesh $J$ Pharmacol, 4(2009):24-28.

[12] Naef, R. The volatile and semi-volatile constituents of agarwood, the infected heartwood of Aquilaria species: A review. Flavour Frag J., 26(2011):73-87.

[13] Pornpunpayat, J., Chetpattananondh, P., Tongurai, C. Mathematical modeling for extraction of essential oil from Aquilaria crassna by hydrodistillation and quality of agarwood oil. Bangladesh J Pharmacol, 6(201):18-24. 